\title{
Influence of cement type and water content on the fresh state properties of ready mix mortar
}

\author{
Influência do tipo de cimento e da quantidade de água \\ nas propriedades do estado fresco das argamassas \\ estabilizadas
}

\section{J uliana Machado Casali \\ Fernanda Domingues Melo \\ Vitoria Carminatti Serpa \\ Alexandre Lima de Oliveira \\ Andrea Murillo Betioli \\ Luciana Maltez Lengler Calçada}

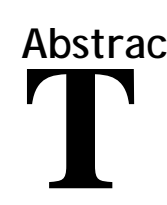

he main characteristic of ready mix mortar is to remain workable for up to 72 hours after mixing. This greater duration of workability is obtained by use of hydration stabilizing admixtures and airentrained admixtures. Thus, the behavior of this mortar depends on the compatibility between Portland cement and these two admixtures. Within this context, the objective of this article is to evaluate the influence of Portland cement type and water content on the properties of ready mix mortars in fresh state. Three types of Portland cement and four water/dry material ratios were evaluated. The produced mortars were analyzed with respect to their properties in fresh state: consistency index, specific gravity, air entrained content and rheological behavior by squeeze-flow. The properties were determined for three storage durations ( 0,24 and 48 hours). The results show that both types of cement (mainly, the rheological behavior) and water content (mainly, the air entrained content, consistency and rheological behavior) influenced the ready mix mortar properties. Therefore, these two parameters must be evaluated for mortar dosages in order to obtain the required properties in fresh state.

J uliana Machado Casali Instituto Federal de Santa Catarina Florianópolis - SC - Brasil

Fernanda Domigues Melo Instituto Federal de Santa Catarina Florianópolis - SC - Brasil

Vitoria Carminatti Serpa Instituto Federal de Santa Catarina Florianópolis - SC - Brasil

Alexandre Lima de Oliveira Instituto Federal de Santa Catarina Florianópolis - SC - Brasil

Andrea Murillo Betioli Instituto Federal de Santa Catarina Florianópolis - SC - Brasil

Luciana Maltez Lengler Calçada Instituto Federal de Santa Catarina Florianópolis - SC - Brasil

Recebido em 20/03/17 Aceito em 15/12/17
Keywords: Ready mix mortar. Rendering mortar. Admixtures.

\section{Resumo}

A principal característica da argamassa estabilizada é manter-se trabalhável por até 72 horas após a mistura. Esse maior tempo trabalhável é obtido em função de aditivos estabilizador de hidratação e incorporador de ar. Assim, o comportamento desta argamassa depende da compatibilidade entre o cimento Portland e esses dois aditivos. Neste contexto, o objetivo deste artigo é avaliar a influência do tipo de cimento Portland e da quantidade de água nas propriedades das argamassas estabilizadas no estado fresco. Foram avaliados três tipos de cimento Portland e quatro relações água / material seco. As argamassas produzidas foram analisadas em relação às suas propriedades em estado fresco: índice de consistência, densidade de massa, teor de ar incorporado e comportamento reológico pelo Squeeze-flow. As propriedades foram determinadas em três tempos de armazenamento (0, 24 e 48 horas). Os resultados mostram que tanto o tipo de cimento (principalmente o comportamento reológico) quanto a quantidade de água (principalmente o teor de ar incorporado, a consistência e o comportamento reológico) influenciaram as propriedades das argamassas estabilizadas. Portanto, esses dois parâmetros devem ser avaliados na dosagem da argamassa estabilizadas para obter as propriedades adequadas no estado fresco.

Palavras-chaves: argamassa estabilizada, argamassa de revestimento, aditivos

CASALI, J. M.; MELO, F. D.; SERPA, V. C.; OLIVEIRA, A. L. de; BETIOLI, A. M.; CALÇADA, L. M. L. Influence of cement 33 type and water content on the fresh state properties of ready mix mortar. Ambiente Construído, Porto Alegre, v. 18, n. 2, p. 33-52, abr./jun. 2018.

ISSN 1678-8621 Associação Nacional de Tecnologia do Ambiente Construído.

http:// dx. doi. org/ 10.1590/ s1678-86212018000200241 


\section{Introduction}

Ready mix mortar is characterized by its capacity to maintain its workability for up to three days, which is achieved by employing hydration stabilizer admixtures. Without the use of such admixtures, ready mix mortar must be used within 2.5 hours after mixing, due to the cement hydration process.

According to Nelson et al. (1988), ready mix mortar was only introduced after the development of special set retarding admixtures, allowing mortar to remain workable for two or three days in the 1970s in Germany[inserir ponto] The authors mention in the paper that they were also specially developed air entraining agents creating a stable air content in mortar over a longer period of time for increased workability .

After many years of use in Europe, ready mix mortar was first used in Canada around 1980 and in the United States in 1982 (PANARESE; KOSMATHA; RANDALL JUNIOR, 1991). In Brazil, one of the first recorded uses of this type of mortar was in 1985 when an external rendering mortar was produced in a central plant in Greater São Paulo (MARTINS NETO; DJANIKIAN, 1999).

Ready mix mortar research studies usually evaluate the properties of mortars dosed by the manufacturer. Important variables in preparing the mortar include control of air content, mixing sequence, temperature, mix design, sand grading and cement and/or lime quality (NICHOLSON, 1987). When analyzing the mortars dosed by the manufacturer, Casali et al. (2011) and some authors found that the storage process influences the mortar's properties. Several authors have shown that there is usually a decrease in the consistency index of the mortars over time of storage (MANN NETO; ANDRADE; SOTO, 2010; PAGNUSSAT; VIDOR; MASUERO, 2012; CASALI et al., 2011; CALÇADA et al., 2013; MACIOSKI, 2014; FIORAVANTE, 2014; JANTSCH, 2015; TURRA, 2016; PIVETTA et al., 2016; KEBHARD; KAZMIERCZAK, 2017). Pagnussat, Vidor and Masuero (2012), Calçada et al. (2013), Fioravante (2014) and Trevisol, Portella and Bragança (2015) found that the air entrained content is influenced by storage duration. Casali et al. (2011), Calçada et al. (2013), Fioravante (2014), Bellei et al. (2015) and Jantsch (2015) observed that the mortar's properties in the hardened state are influenced by storage duration. However, Nelson et al. (1989), Trevisol, Portella and Bragança (2015) and Kebhard and Kazmierczak (2017) did not observe differences in compressive strength over the storage duration. Bellei et al. (2015) indicated that the $36 \mathrm{~h}$ ready mix mortar achieved superior performance in both the fresh and hardened state, in comparison to the $72 \mathrm{~h}$ mortar. These authors also noticed that the amount of air-entraining admixture used influenced the mortar's performance. Macioski et al. (2013) and Bauer et al. (2015) observed variability in different batches of the same ready mix mortar. Therefore, there are few studies concerning the variability of ready mix mortar during storage time and in different batches.

The materials used for ready mix mortar are the same as the ones for conventional mortar produced on site (consisting of binders - Portland cement and/or lime - sand and water), except that the mortar contains a special set-controlling (extendedlife) admixture that keeps the mortar plastic and workable for a period of more than 2.5 hours (usually 24 to 36 hours), and up to 72 hours with certain admixtures (PANARESE; KOSMATHA; RANDALL JUNIOR, 1991). The admixture system is critical to the success of the ready mix mortar. The important variables in the admixtures system are the choice of retarders, moisture retention agents and water reducers to obtain optimum results (NICHOLSON, 1987). The basic admixtures system in Brazil is composed of a hydration stabilizing admixture and an air-entraining admixture (MANN NETO; ANDRADE; SOTO, 2010; NUNES, 2010; FIORAVANTE, 2014; BAUER et al., 2015; JANTSCH, 2015; TURRA, 2016; KEBHARD; KAZMIERCZAK, 2017). The hydration stabilizing admixture is used to extend the duration of the workability. In addition to this admixture, an air-entraining admixture is usually employed to improve workability (CARASEK, 2010).

With respect to the hydration stabilizing admixture for stabilized mortars, Campos (2012) and other authors such as Pivetta et al. (2016) and Ruppenthal and Pelisser (2012) found an increase in the initial setting time as the admixture content increased. Also, for the same admixture content, storage time did not influence the initial setting time (RUPPENTHAL; PELISSER, 2012). However, this author did not evaluate the properties of this admixture when combined with an air-entraining admixture, nor did he assess the effect of the water content or cement type.

Bauer and Oliveira (2017) found that mortar that only had a hydration stabilizing admixture (and no other admixture) presented a lower mechanical resistance and an increased capillary coefficient. However, after adding an air-entraining admixture as well, these authors observed a reduction in the water content, contributing positively to the mechanical properties and capillary absorption of 
the ready mix mortars. Fioravante (2014) observed that hydration stabilizing admixtures are the ones that most affect the compressive strength of the mortars, yielding lower values for higher contents of this admixture.

On the topic of air-entraining admixtures, Romano (2013) observed that the foaming capacity is influenced by the air-entraining admixture content and water content. The author found that the cement hydration reaction was not influenced by the airentraining admixture. As the production of ready mix mortar largely employs these two admixtures together, it is necessary to study mortar behavior using them all.

With regard to the cement type, Nicholson (1987) reported that their experience demonstrated that a blend of Portland cement with masonry cement is often a better choice for ready mix mortar, but did not explain the reason. Mattana Júnior and Costa (2009) evaluated three types of Portland cement (CP II - F - 32, CP II - Z - 32 and CP IV - 32) in mortar with a 1: 2.5 (cement: sand) volume ratio and a water/dry materials ratio of $16.2 \%$. The authors observed that the type of cement influences the rheological behavior of mortars and that the squeeze flow was sensitive enough to show this influence. However, in this study, no hydration stabilizing additive was used and, therefore, the influence of using an air-entraining admixture combined with a hydration stabilizer admixture was not studied. This research clearly shows that cement type influences the mortar's fresh state behavior, indicating that it is important to study how cement type influences the ready mix mortar.

The properties of ready mix mortars are not fully known because few studies have been published on this topic. There is no Brazilian standard regarding this type of mortar and Bauer et al. (2015) urgently suggested creating a ABNT committee for working on the development of specifications especially for ready mix mortars. Normally, the standards employed are those concerning the use of mortar as bedding joint or rendering mortars, for example, or adaptations of Portland cement and concrete standards. However, certain procedures, such as the evaluation of the workability as a function of storage duration, are not presented in these standards.

Wtihin this context, the objective of this research is to evaluate the influence of cement type and water content on the fresh state properties of ready mix mortar.

\section{Materials and methods Characterization of materials used}

Three different types of Portland cement, provided by a local cement company, and complying with Brazilian standards, were used in this research: Cement A - Portland cement composite with Filer (CP II - F - 32: Portland cement containing approximately $10 \%$ of limestone filler) according to NBR 11578 (ABNT, 1997); Cement B - Portland cement composite with pozzolan (CP II - Z - 32: Portland cement containing approximately $10 \%$ of limestone filler and $10 \%$ of fly ash according to NBR 11578 (ABNT, 1997) and Cement C Pozolanic Portland Cement (CP IV - 32: Portland cement containing approximately $6 \%$ of limestone filler and 25\% of fly ash) according to NBR 5736 (ABNT, 1999). These types of Portland cement were chosen because they are the most commonly used in southern Brazil, where the research was conducted. The chemical and physical characteristics of the cements used are shown in Table 1.

The particle size distribution of three types of Portland cement was obtained by laser diffraction. Figure 1 and Table 1 illustrate how each type of cement can obtain different particle size distributions, for example, Cement B.

The aggregate was provided by a local ready mix mortar manufacturer; a natural sand was used to produce a rendering mortar that is well accepted in the consumer market. The sand characteristics were evaluated with respect to the following properties: granulometric composition (ABNT, 2003a), apparent specific mass (ABNT, 2009) and powder content (ABNT, 2003b). These characteristics are presented in Table 2.

A hydration stabilizer admixture and an airentraining admixture (both from the same manufacturer) were used. The manufacturer recommended using the two additives together. Moreover, there were no recommendations against using these admixtures with the three Portland cements selected for this study. The characteristics of the admixtures used, provided by the manufacturer, are shown in Table 3.

\section{Production and properties of stabilized mortars}

To evaluate the fresh state properties of the stabilized mortars, a mass ratio of 1:6 (cement: sand) was used for all tested mortars. This ratio was used by Martins Neto and Djanikian (1999), Fioravante (2014) and Bauer and Oliveira (2017) for ready mix mortar. The amount of stabilizer 
admixture and air-entraining admixture was $0.8 \%$ and $0.35 \%$ of cement mass, respectively, established from a dosage study performed with cement A to obtain adequate application conditions for a period of 72 hours. These admixture contents were applied to the three types of cement in order to evaluate the influence of cement type when the content of the other constituents of the mortar remained constant.

In addition to varying the type of cement, four water/dry materials $(\mathrm{H})$ ratios were also evaluated:
$12 \%, 13.5 \%, 15 \%$ and $16.5 \%$. These values were defined based on results obtained by Bauer et al. (2015) involving 17 lots of ready mix rendering mortar that were applied in construction. In this study, the water/dry materials ratios $(\mathrm{H})$ found were between $12.3 \%$ and $19.4 \%$. Thus, with the lowest water/dry materials $(\mathrm{H})$ ratio $(12 \%)$ and Cement A (smaller amount of additions), it was possible to obtain a workable rendering mortar slightly dryer than usual. Moreover, the maximum water/dry materials $(\mathrm{H})$ ratio was $16.5 \%$ to obtain workable rendering mortar slightly more fluid than usual.

Table 1 - Portland cement characteristics

\begin{tabular}{|c|c|c|c|}
\hline \multicolumn{4}{|c|}{ Physical Properties } \\
\hline Control Item & Cement A & Cement B & Cement C \\
\hline $\begin{array}{l}\text { Retained content \#200 (mesh) (\%) } \\
\text { Retained content \#325 (mesh) (\%) } \\
\text { Specific Surface - Blaine (cm²/g)* } \\
\text { Normal Consistent water content (\%) } \\
\text { Initial Setting time (hours) } \\
\text { End of setting time (hours) } \\
\text { Hot Expansibility (mm) } \\
\text { Compressive Strength at } 1 \text { day (MPa) } \\
\text { Compressive Strength at } 3 \text { day (MPa) } \\
\text { Compressive Strength at } 7 \text { day (MPa) } \\
\text { Compressive Strength at } 28 \text { day (MPa) } \\
\text { Specific Gravity (g/cm³)* }\end{array}$ & $\begin{array}{c}2.10 \\
12.30 \\
3102 \\
27.2 \\
4: 20 \\
5: 00 \\
0.00 \\
13.9 \\
29.4 \\
34.9 \\
42.7 \\
3.15\end{array}$ & $\begin{array}{l}1.90 \\
8.00 \\
4356 \\
27.7 \\
4: 20 \\
5: 00 \\
0.00 \\
11.2 \\
24.0 \\
32.1 \\
39.4 \\
3.07\end{array}$ & $\begin{array}{c}0.50 \\
2.80 \\
3441 \\
30.0 \\
4: 40 \\
5: 30 \\
0.00 \\
12.8 \\
26.90 \\
34.90 \\
44.80 \\
2.97\end{array}$ \\
\hline \multicolumn{4}{|c|}{ Chemical Properties } \\
\hline \begin{tabular}{|c|} 
Control Item \\
\end{tabular} & Cement A & Cement B & Cement C \\
\hline $\begin{array}{l}\mathrm{SiO}_{2}(\%) \\
\mathrm{Al}_{2} \mathrm{O}_{3}(\%) \\
\mathrm{Fe}_{2} \mathrm{O}_{3}(\%) \\
\mathrm{CaO}(\%) \\
\mathrm{MgO}(\%) \\
\mathrm{SO}_{3}(\%) \\
\text { Ignition loss (\%) } \\
\text { Insoluble Residue (\%)* }\end{array}$ & $\begin{array}{c}18.97 \\
4.22 \\
2.79 \\
61.98 \\
3.43 \\
2.55 \\
3.93 \\
1.18 \\
\end{array}$ & $\begin{array}{c}19.39 \\
4.23 \\
2.87 \\
62.41 \\
3.71 \\
3.13 \\
2.32 \\
0.72\end{array}$ & $\begin{array}{c}22.67 \\
6.01 \\
3.10 \\
56.76 \\
3.47 \\
2.16 \\
3.71 \\
9.07\end{array}$ \\
\hline
\end{tabular}

Source: results presented by the Cement manufacturer.

Note: *results obtained by the authors. 
Figure 1 - Particle size distribution by laser diffraction of three types of Portland cement

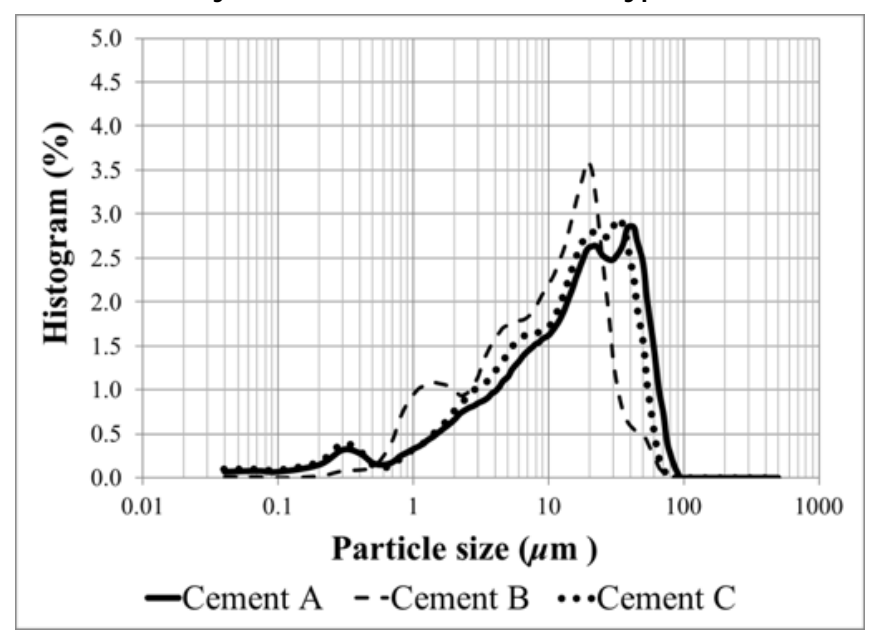

Table 2 - Physical properties of the sand

\begin{tabular}{l|c}
\hline \multicolumn{1}{c|}{ Meshes opening (mm) } & Cumulative Retained Percentage (\%) \\
\hline 4.8 & 0.0 \\
2.4 & 0.1 \\
1.2 & 2.2 \\
0.6 & 13.5 \\
0.3 & 44.7 \\
0.15 & 87.7 \\
Bottom & 100 \\
Characteristic maximum dimension (mm) & 1.2 \\
Characteristic minimum dimension (mm) & $<0.15$ \\
Fineness Module & 1.48 \\
Specific Gravity (g/cm $\left.{ }^{3}\right)$ & 2.64 \\
Powder content $(\%)$ & 0.44 \\
\hline
\end{tabular}

Table 3 - Characteristics of the admixtures used

\begin{tabular}{|c|c|c|}
\hline Admixture & Hydration stabilizer admixture & Air-entraining admixture \\
\hline Function & $\begin{array}{l}\text { Mortar plasticizer and hydration } \\
\text { stabilizer }\end{array}$ & Air-entrained for mortar \\
\hline $\begin{array}{l}\text { Chemical Base } \\
\text { (Component of greater quantity) }\end{array}$ & Carbohydrates & $\begin{array}{c}\text { Organic salts } \\
\text { (Sodium lauryl ether sulfate salt } \\
\text { and sodium alkyl ether sulphate) }\end{array}$ \\
\hline Solid content (\%) & 39.98 & 14.15 \\
\hline Specific gravity in $25^{\circ} \mathrm{C}\left(\mathrm{g} / \mathrm{cm}^{3}\right)$ & 1.1 & 1.1 \\
\hline $\mathrm{pH}\left(23^{\circ} \mathrm{C}\right)$ & 8 & 6 \\
\hline Physical state & Liquid & Liquid \\
\hline Color & $\begin{array}{c}\text { Transparent slightly } \\
\text { yellowish }\end{array}$ & Dark brown \\
\hline Recommended dosage & 0.1 a $0.9 \%$ by cement mass content & $\begin{array}{c}0.2 \text { a } 1.0 \% \text { by cement mass } \\
\text { content }\end{array}$ \\
\hline
\end{tabular}

Source: results presented by the admixture manufacturer.

The materials were mixed using a 51 laboratory mechanical mortar mixer. The mixing sequence was determined to simulate the mixing of materials during production of stabilized mortars, and was carried out as follows: (a) placing half of the sand, then the entire amount of cement, and finally the other half of the sand in the bowl;

(b) mixing the mortar for 30 s at speed 1 ; 
(c) stop mixing, adding $80 \%$ of the amount of water and then mixing for 30 s at speed 1 ;

(d) stop mixing and adding the air-entraining admixture, then mixing for 60s at speed 1 .

(e) stop mixing for 60 s to scrape the bowl sides and blade; and

(f) adding the hydration stabilizer and the remaining water (20\%), then mixing for 120 s at speed 1.

The time of mixture described at the $6^{\text {th }}$ step of the mixing procedure was determined in a preliminary study conducted to find the higher possible entrained air content. For the air-entraining admixture used in this work, when mixing more than 120s, the air content does not vary anymore.

The mortars were evaluated after storage, with three different storage durations, calculated from the time of their mixture: 0 hours, 24 hours and 48 hours. For each duration, a mixture was carried out in a laboratory mechanical mortar mixer, which means there were three different mixtures. To verify the homogeneity of these three mixtures, air entrained content and specific gravity (ABNT, 2005a) were evaluated immediately after the mixing of all mixtures at 0 hours. The mixtures that would be evaluated at 24 and 48 hours were stored separately in sealed containers. To check the system's watertightness and a possible loss of water, the sealed containers were weighted twice: once at 0 hours and again on the date that the mortar properties were measured. In all cases there was no difference in the mass of the sealed containers with mortar.
For the mixture evaluated at 0 hours, immediately after the mixing, the air entrained content and the specific gravity (according to NBR 13278 (ABNT, 2005)), the consistency (consistency index - flow table) (according to NBR 13276 (ABNT, 2005b)) and rheological behavior (evaluation by squeezeflow) (ABNT, 2010) were determined.

For the mixtures evaluated at 24 and 48 hours, before evaluating the same properties described above, the mortars were homogenized using the laboratory mechanical mortar mixer for 120 seconds at speed 1 (the air content does not vary anymore from this time). This procedure was done due to the results presented by Fernandes (2011) and Pereira (2012) that studied commercial ready mix mortar and reported that they segregate during storage. It should be mentioned that in other studies, mortars were also homogenized before the evaluation after different storage duration (MANN NETO; ANDRADE; SOTO, 2010; MACIOSKI, 2014; JANTSCH, 2015), and this procedure is recommended by some manufacturers (BENNTER, 2017; SUPERMIX, 2017).

A summary of mortars and storage duration are presented in Table 4.

\section{Results and discussion}

The air entrained content was evaluated immediately after the mixing process; results can be seen in Figure 2 for mortars with three types of cement at time 0 hours. For each water/dry materials ratio, the air entrained content value was calculated by averaging measurements on three different samples.

Table 4 - Summary of mortar characteristics and storage duration

\begin{tabular}{c|c|ccc}
\hline $\begin{array}{c}\text { Portland } \\
\text { Cement }\end{array}$ & $\begin{array}{c}\text { Water/dry materials } \\
\mathbf{( \% )}\end{array}$ & \multicolumn{3}{|c}{$\begin{array}{c}\text { Storage duration } \\
\text { before analysis (h) }\end{array}$} \\
\hline \multirow{3}{*}{ A } & 12.0 & 0 & 24 & 48 \\
& 13.5 & 0 & 24 & 48 \\
& 15.0 & 0 & 24 & 48 \\
& 16.5 & 0 & 24 & 48 \\
\hline \multirow{3}{*}{ B } & 12.0 & 0 & 24 & 48 \\
& 13.5 & 0 & 24 & 48 \\
& 15.0 & 0 & 24 & 48 \\
C & 16.5 & 0 & 24 & 48 \\
\hline & 12.0 & 0 & 24 & 48 \\
& 13.5 & 0 & 24 & 48 \\
& 15.0 & 0 & 24 & 48 \\
& 16.5 & 0 & 24 & 48 \\
\hline
\end{tabular}


Figure 2 - Air entrained content for the mortars with three types of cement at 0 hours

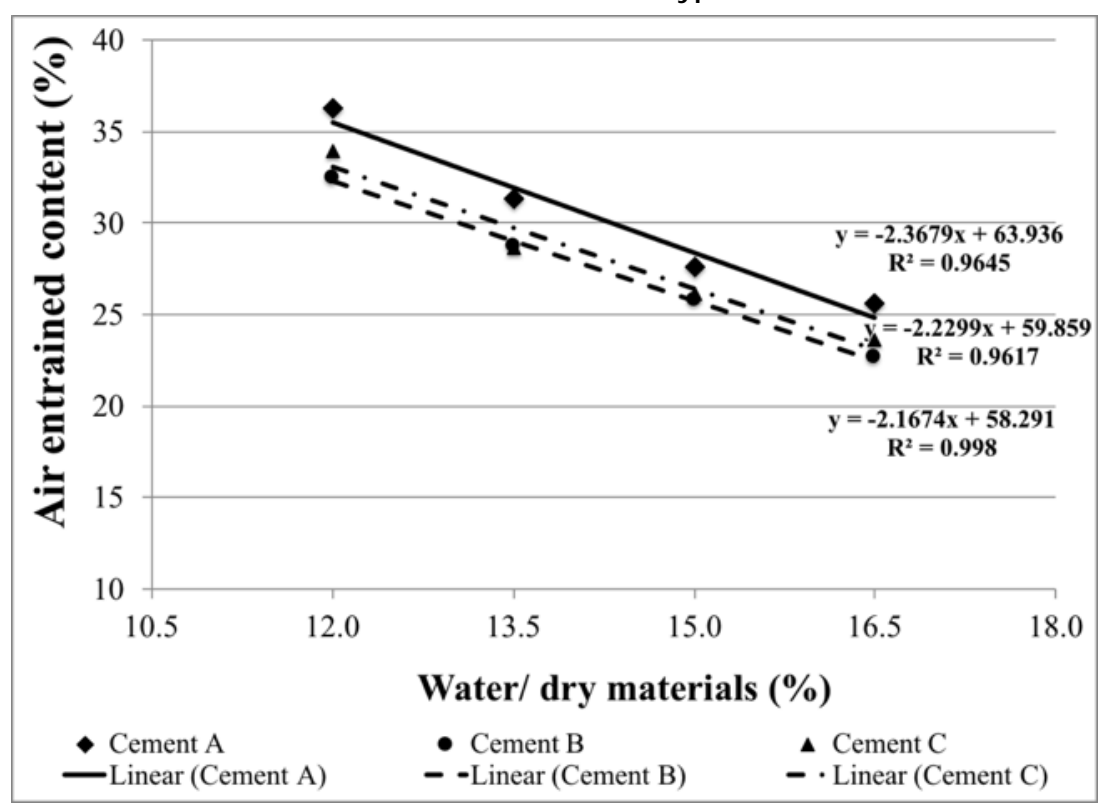

As shown in Figure 2, as the water/dry materials ratio increases, the air entrained content decreases. This behavior was observed with a high degree of linear correlation for the three types of cement obtaining. The highest values of air entrained content were obtained with Portland cement $\mathrm{A}$ and the smallest were obtained with the Portland cement $\mathrm{B}$, considering the same water/dry materials ratio. It should be noted, as well, that the values obtained for mortars with Portland cement B and Portland cement $\mathrm{C}$ (both cements containing fly ash in the composition) were very similar. However, statistically (with 95\% confidence level in regression analysis), the cement type had no significant influence on air entrained content. On the other hand, the water/dry materials ratio did have a significant influence.

The air entrained content observed for $12 \%$ and $13,5 \%$ water/dry materials are higher than those observed in commercial ready mix mortars. This behavior is probably due to the high efficiency of the mixer used in this work in comparison to the ones utilized to produce commercial ready mix mortars. Also, the mixing process utilized allowed reachingh the higher air entrained content,which was possible with the admixture and mixer used. Since the aim of this work was not to reach an air entrained content but to study the influence of water/dry materials influence in the air entrained content, the air entrained content observed for $12 \%$ and $13,5 \%$ were taken into consideration.

The effect of the amount of water in mortars with air-entrained admixtures was also studied by Romano (2013), who found that the greater the amount of water in the mortar mixture, the greater the air entrained content. The author stated that the generation of bubbles depends on the presence of free water in the suspension.

The main property that is usually controlled in fresh state during ready mix mortar production is the air entrained content. Therefore, cement type and the water/dry materials ratio must be considered as they influence this property.

The values of air entrained content, for mortars with three types of cement, after 24 hours and 48 hours of storage, are shown in Figures 3 and 4.

For storage durations of 24 hours and 48 hours, (Figures 3 and 4), the same trend was observed as for 0 hours: as the water/dry materials ratio increased the air content decreased. However, as the water/dry materials ratio increased, the difference in air content between the Portland cement $\mathrm{A}$ and the other cement types decreased, and for the 16,5\% water/dry materials ratio, the air content was similar for all cement types. Again, for the Portland cement $\mathrm{B}$ and Portland cement $\mathrm{C}$, the air content values were very similar for all water/ dry materials ratios.

The consistency index of the mortars analysed with three types of cement at 0 hours is presented in Figure 5.

As expected, Figure 5 shows that the consistency index increased as the water/ dry materials increased. For the $12 \%$ water/ dry materials ratio, the consistency index was not influenced by cement type. It should be mentioned that the highest value of air entrained content was observed for this water/ dry materials ratio (Figure 2), which may explain this behavior. 
Figure 3 - Air entrained content for mortars with three types of cement after 24 hours of storage

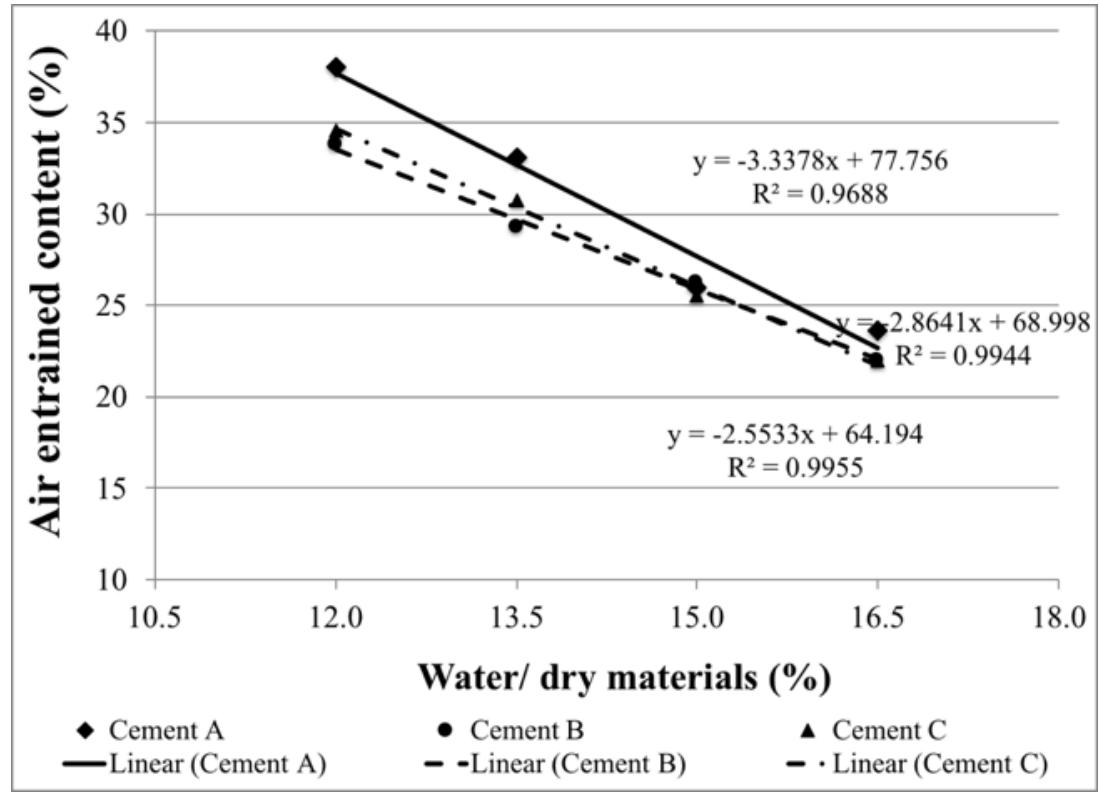

Figure 4 - Air entrained content for the mortars with three types of cement after 48 hours of storage

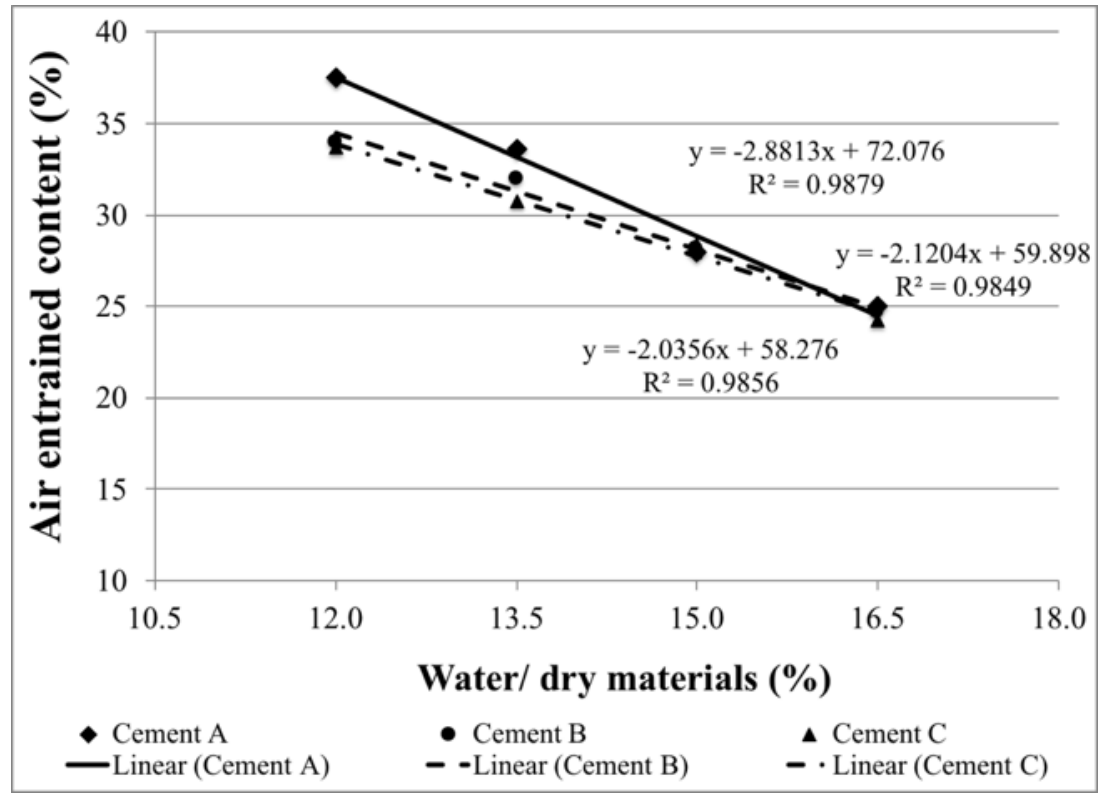


Figure 5 - Consistency index for mortars with three types of cement at 0 hours

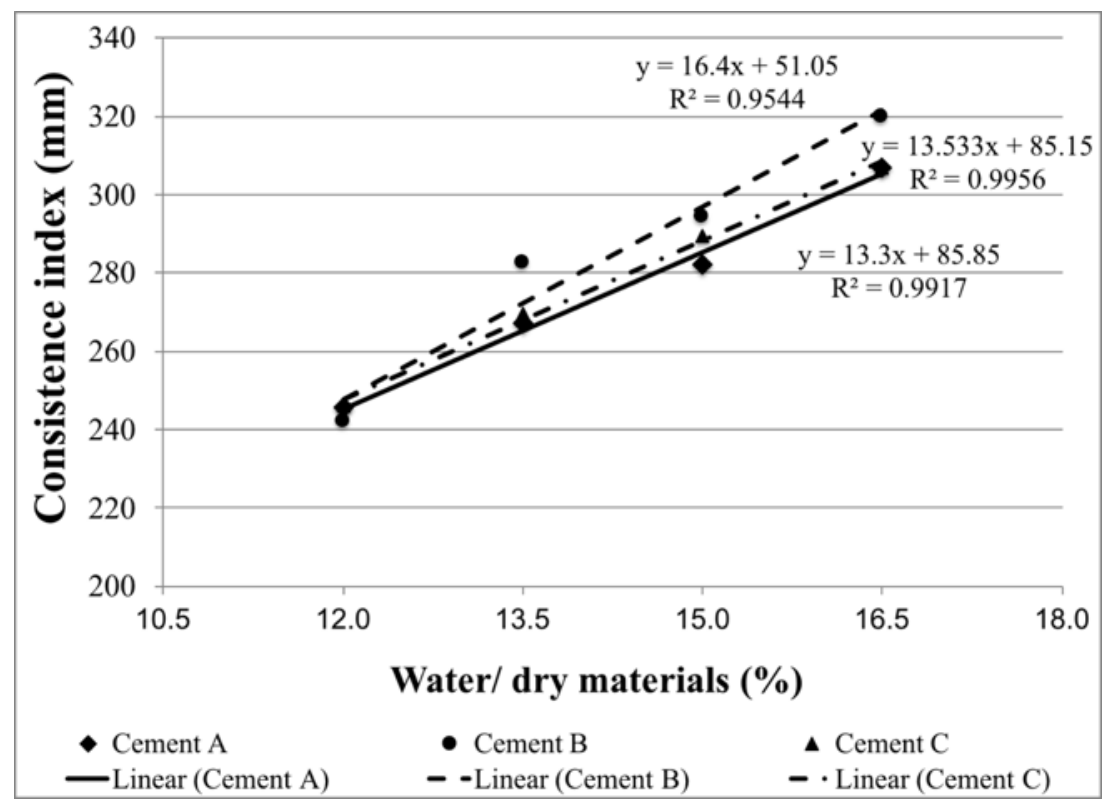

For the other values of water/dry materials ratio, the highest consistency index was obtained for mortars containing Portland cement $\mathrm{B}$ and the consistence index for Portland cement A and Portland cement $\mathrm{C}$ were similar to each other. This behavior was probably due to the particle size distribution presented in Figure 1 where it can be seen that the curves that represent Portland cement $\mathrm{A}$ and Portland cement $\mathrm{C}$ are similar to each other and Portland cement B has finer particles.

The results obtained for consistency index and air entrained content over time of storage $(0,24$ and 48 hours) for all mortars are shown in Table 5.

Table 5 shows that, for almost all mortars, there was a reduction in the consistency index as storage duration increased. It is suspected that this behavior is due to the beginning of the cement hydration reaction. These results for loss of the consistency index over the storage duration were also obtained by Casali et al. (2011), Pagnussat, Vidar and Masuero (2012); Calçada et al. (2013) and Macioski (2014). It is most likely that the homogenizing procedure, before the evaluation of the mortars after $24 \mathrm{~h}$ and $48 \mathrm{~h}$ of storage, recovered the air entrained content observed when the mortar was analyzed immediately after production.

The squeeze-flow behavior for mortars containing Portland cement A with different storage durations are shown in Figure 6.

Figure 6 shows that the water/dry materials ratio influences the rheological behavior by squeezeflow. As the water/dry materials ratio increases, resistance to displacement applied to the mortar increases. As demonstrated in Figure 7a, there was a high degree of linear correlation between the water/dry materials ratio shown and the maximum displacements obtained by squeeze-flow. It should be mentioned that the water/dry materials ratio is one of the main control parameters used in convention mortar production.

Air entrained content also influenced the results. The linear correlation between air entrained content and the maximum displacements obtained by squeeze-flow is shown in Figure $7 \mathrm{~b}$.

The higher the air entrained contents, the smaller the load needed to squeeze the mortar, consequently the greater the displacement obtained. Air acts on the paste, increases its volume and moves away the aggregates (reducing the friction between them) (CARDOSO, 2010). Air also changes certain characteristics, such as the increase of the cohesion of the paste and the reduction of the tendency to segregate.

With respect to storage duration, results show that there was a small increase of the maximum displacement as storage duration increased. It should be noted that values for air entrained contents were similar for different storage durations (Table 5), but there was a reduction in the consistency index of the mortars (Table 5). 
Table 5 - Consistency index and air entrained content over time of storage for all mortars

\begin{tabular}{|c|c|c|c|c|c|c|c|}
\hline \multirow[b]{3}{*}{ Portland Cement } & \multirow[b]{3}{*}{$\begin{array}{l}\text { H* }^{*} \\
\text { (\%) }\end{array}$} & \multicolumn{6}{|c|}{ Storage duration } \\
\hline & & \multicolumn{2}{|c|}{0 hours } & \multicolumn{2}{|c|}{24 hours } & \multicolumn{2}{|c|}{48 hours } \\
\hline & & $\begin{array}{l}\text { CI** } \\
\text { (mm) }\end{array}$ & $\begin{array}{c}\text { AEC** } \\
(\%)\end{array}$ & $\begin{array}{l}\text { CI** } \\
(\mathbf{m m})\end{array}$ & $\begin{array}{c}\text { AEC** } \\
(\%)\end{array}$ & $\begin{array}{l}\text { CI** } \\
(\mathbf{m m})\end{array}$ & $\begin{array}{c}\text { AEC** } \\
(\%)\end{array}$ \\
\hline \multirow{4}{*}{ A } & 12.0 & 245.5 & 36.25 & 234.0 & 37.99 & 222.0 & 37.51 \\
\hline & 13.5 & 267.0 & 31.30 & 255.5 & 33.10 & 248.5 & 33.61 \\
\hline & 15.0 & 282.0 & 27.57 & 274.5 & 26.01 & 271.5 & 27.98 \\
\hline & 16.5 & 307.0 & 25.65 & 284.0 & 23.67 & 293.5 & 24.98 \\
\hline \multirow{4}{*}{ B } & 12.0 & 242.0 & 32.46 & 242.5 & 33.75 & 228.5 & 33.98 \\
\hline & 13.5 & 282.5 & 28.78 & 249.5 & 29.28 & 248.0 & 31.97 \\
\hline & 15.0 & 294.5 & 25.77 & 265.0 & 26.20 & 261.5 & 28.12 \\
\hline & 16.5 & 320.0 & 22.62 & 306.5 & 22.01 & 288.0 & 24.66 \\
\hline \multirow{4}{*}{$\mathrm{C}$} & 12.0 & 246.0 & 33.92 & 239.0 & 34.53 & 233.0 & 33.67 \\
\hline & 13.5 & 269.5 & 28.68 & 261.0 & 30.75 & 258.0 & 30.72 \\
\hline & 15.0 & 289.5 & 26.11 & 274.5 & 25.50 & 270.0 & 28.42 \\
\hline & 16.5 & 307.0 & 23.63 & 295.0 & 21.96 & 291.0 & 24.26 \\
\hline
\end{tabular}

Note: *water/ dry materials ratio; ${ }^{* *}$ consistency index; and

**aair entrained content.

Figure 6 - Load versus displacement plots obtained by squeeze-flow for mortars containing Portland cement A: (a) 0 hours of storage; (b) 24 hours of storage; and (c) 48 hours of storage

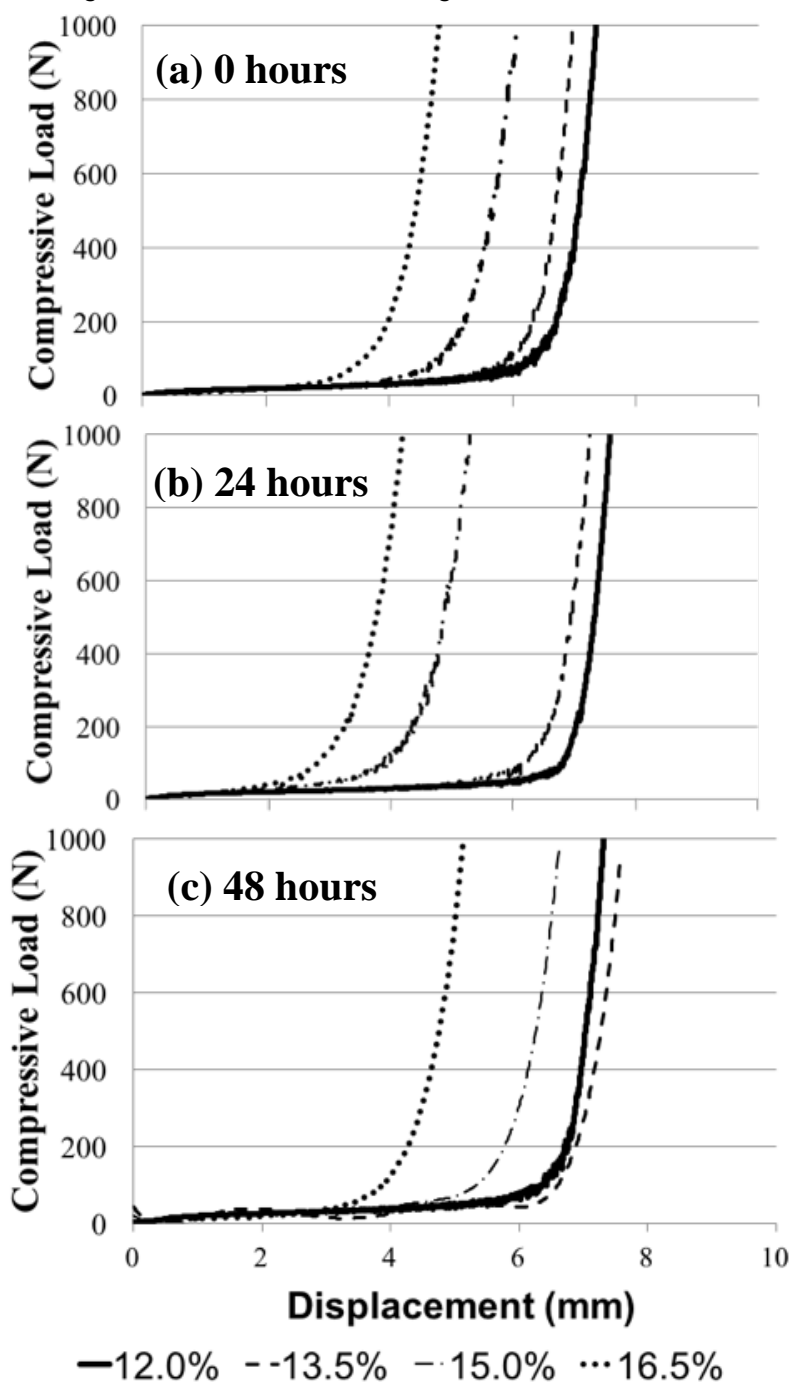


Figure 7 - Correlation of the obtained values of the maximum displacement for mortars containing Portland cement A: (a) water/dry materials; and (b) air entrained content

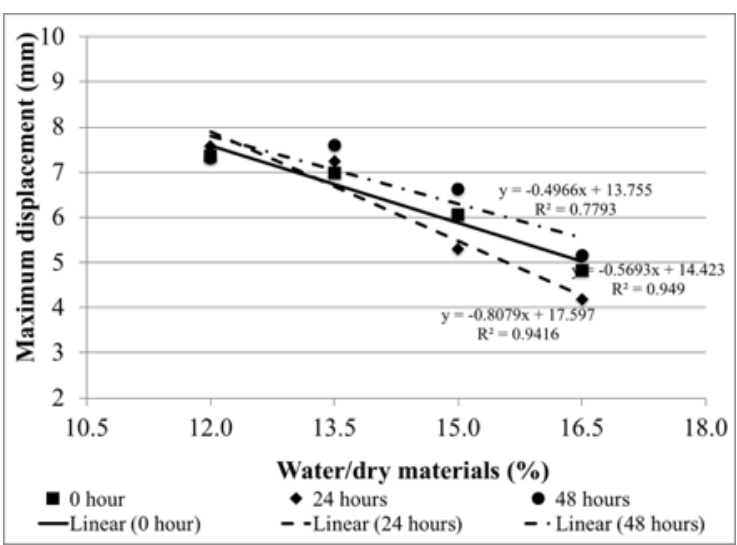

(a)

The values obtained from the rheological behavior for the mortar containing Portland cement $\mathrm{B}$ are presented in Figure 8.

As observed in Figure 8, the behavior of the mortar with Portland cement B was similar to that obtained for the mortar containing Portland cement A for 0 hours of storage (as the water/dry materials ratio increases, resistance to displacement applied to the mortar increases). As already expected, there was a correlation between the water/dry materials ratio and the maximum displacement, as well as a correlation between air entrained content and the maximum displacement, which are shown in Figures 9a and 9b, respectively. Results show that the correlations obtained for mortars with Portland cement B were lower than those for mortars with Portland cement A. It should be noted that there is still a trend in the correlations.

Regarding storage duration, results shows that there was an increase of the maximum displacement as the duration increased, mainly for mortar with $16.5 \%$ water/dry materials ratio. For 48 hours of storage, it should be noted that the rheological behavior was similar for mortars with different water/dry materials ratio, but there was a difference in the values of air entrained contents and in the

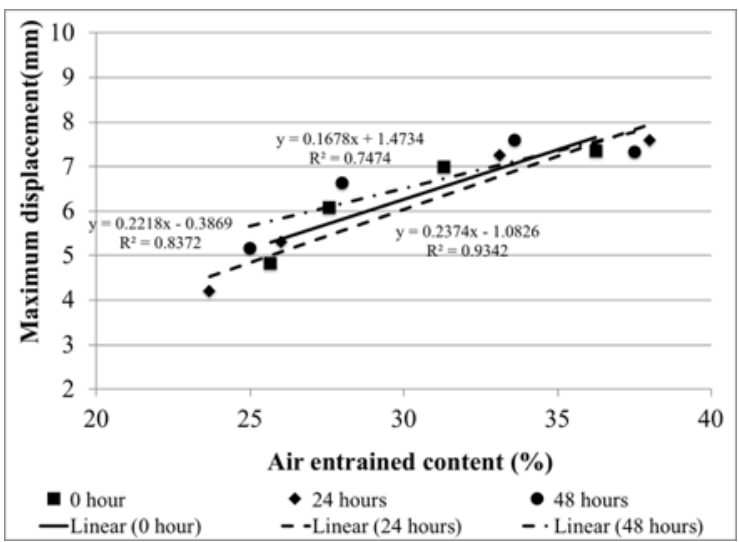

(b)

consistency index of these mortars (Table 5). It could be a possible water loss by evaporation, but there was no mass loss during storage (as mentioned in Materials and Method section). Another possibility is the loss of efficiency of the hydration stabilizer admixture. In this case, the Portland cement hydration could have started and, consequently, the amount of available water in the system decreased. With less water the contribution of the air entrained content to mortar displacement in the squeeze flow test increased, leading to higher displacements. For mortars with $16.5 \%$ water/dry materials ratio, the amount of available water in 0 hours of storage was higher, so the mortars tended to segregate. However, for this mortar, with 48 hours of storage, due to the lowest amount of available water, the effect of incorporated air was higher, reducing the friction between the particles, obtaining a greater displacement. This effect was more pronounced for mortar with $16.5 \%$ water/dry materials ratio, but occurs for all mortars studied (Figure 8).

Figure 10 shows the results of the rheological behavior by squeeze-flow for mortars containing Portland cement $\mathrm{C}$ for all storage durations. 
Figure 8 - Load versus displacement plots obtained by squeeze-flow for mortars containing Portland cement B: (a) 0 hours of storage; (b) 24 hours of storage; and (c) 48 horas of storage
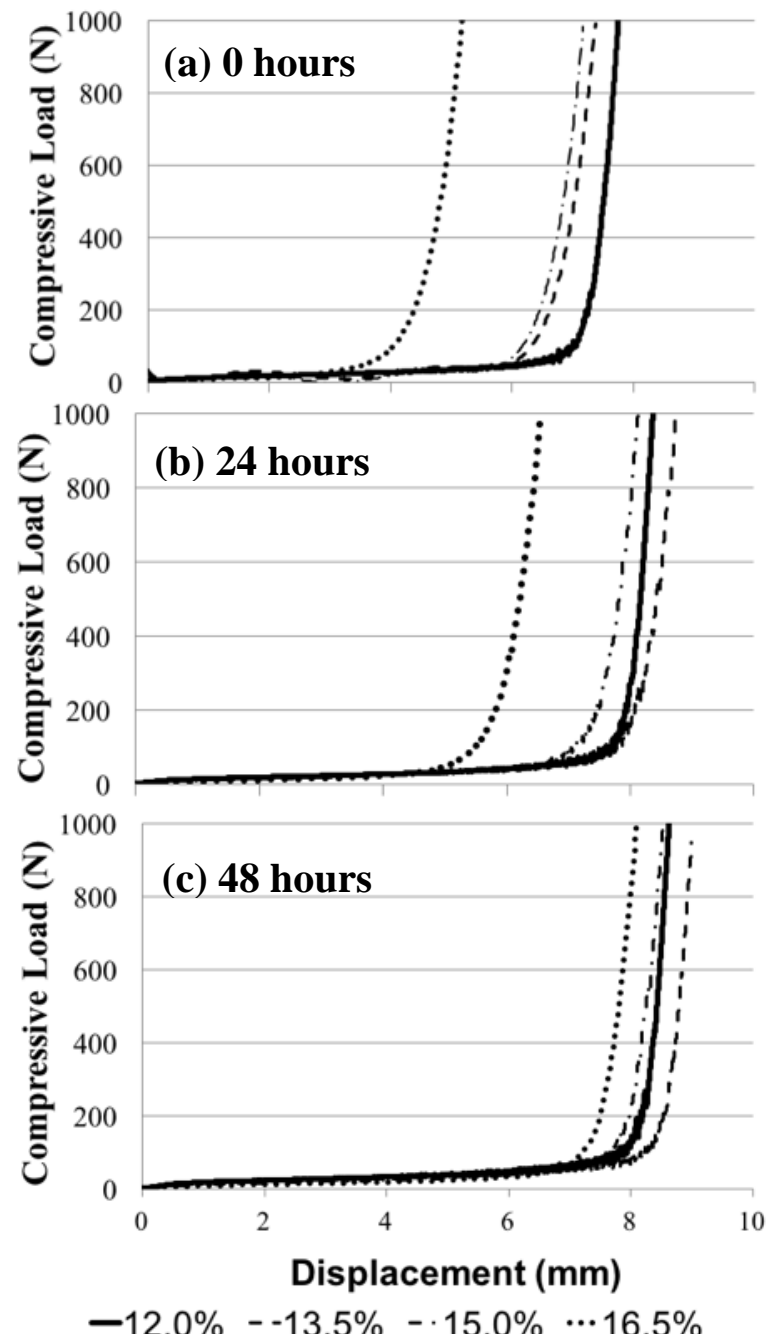

Figure 9 - Correlation of the obtained values of the maximum displacement for mortars containing Portland cement B: (a) water/dry materials; and (b) air entrained content

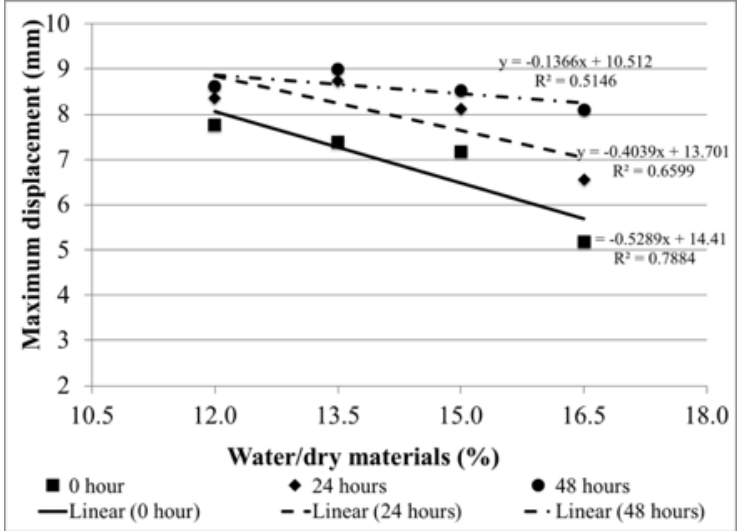

(a)

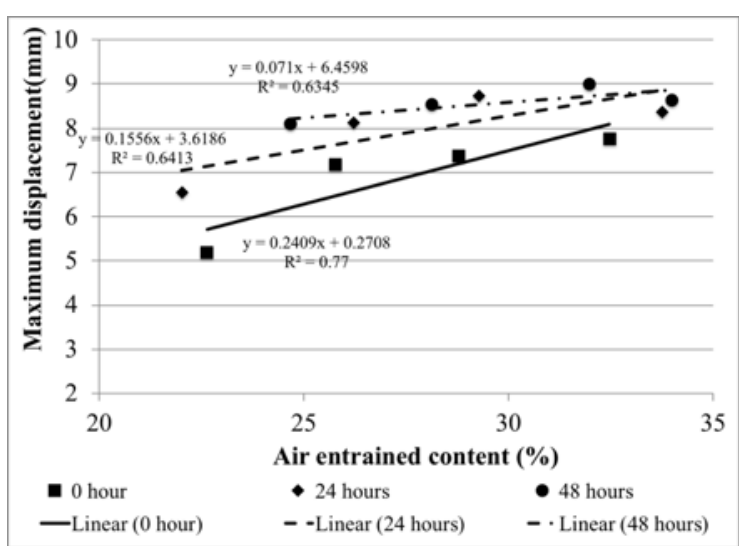

(b) 
Figure 10 - Load versus displacement plots obtained by squeeze-flow for mortars containing Portland cement C: (a) 0 hours of storage; (b) 24 hours of storage; and (c) 48 hours of storage

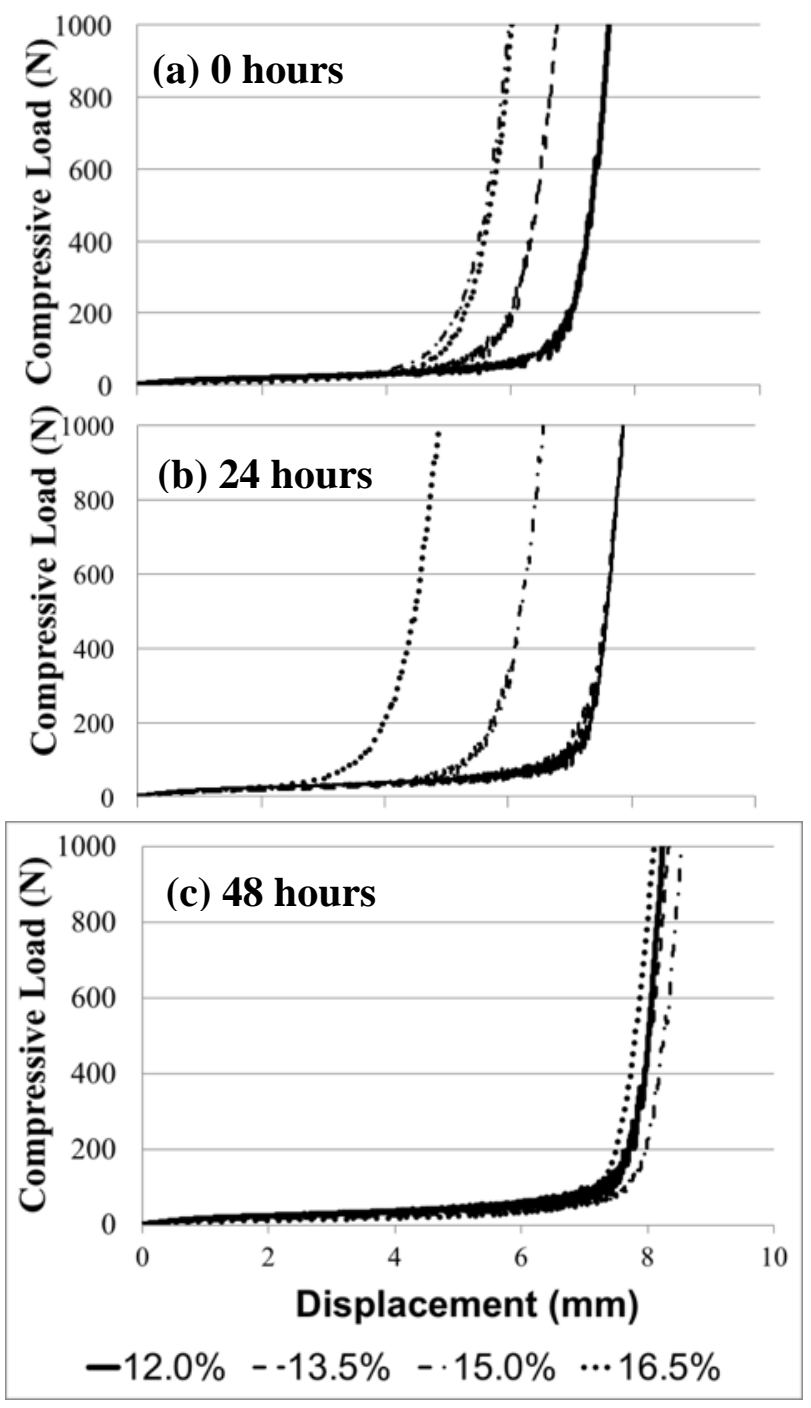

For mortars containing Portland cement $\mathrm{C}$, the influence of the water/dry material ratio on displacement was observed for 0 hours and 24 hours of storage (Figure 10). For 48 hours of storage, there were no observed differences between the curves obtained by squeeze-flow (Figure 10) as mortars containing Portland cement B. For this storage duration, there was no correlation between the maximum displacement and the water/dry materials ratio or the air entrained content, as the maximum displacement remains more or less constant (Figure 11).

The comparison between the types of cement for mortars with a $12.0 \%$ water/dry materials ratio studied after 0, 24 and 48 hours of storage is shown in Figure 12.

For 0 hours of storage, small differences were observed between the curves obtained by squeeze- flow for mortars with different Portland cements (Figure 12a). However, as the storage time increased, there was an increase in the maximum displacement of the mortars with the same Portland cement and differences between the types of Portland cement were observed. The finest Portland cement (Cement B) (Table 1) presented the greatest maximum displacement; the smallest displacement was observed for the thickest Portland cement (Cement A). It should be noted that the air entrained content was not influenced by storage duration; for mortar with Portland cement A, it was around 37\% and for mortars with Portland cement B and Portland cement C, it was around 33\% (Table 5).

The same behavior that was observed in mortars with a $12 \%$ water/ dry materials ratio was observed for mortars with a water/ dry materials ratio of 13.5\% (Figure 13). 
Figure 11 - Correlation of the obtained values of the maximum displacement for mortars containing Portland cement C: (a) water/dry materials; and (b) air entrained content

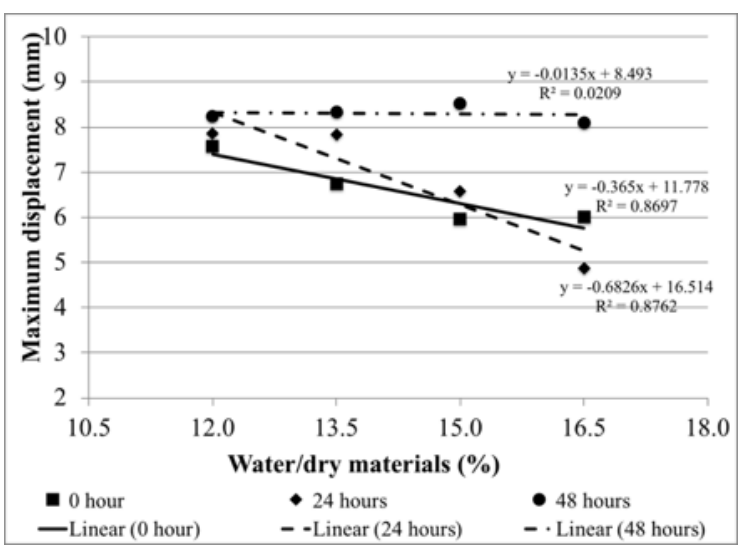

(a)

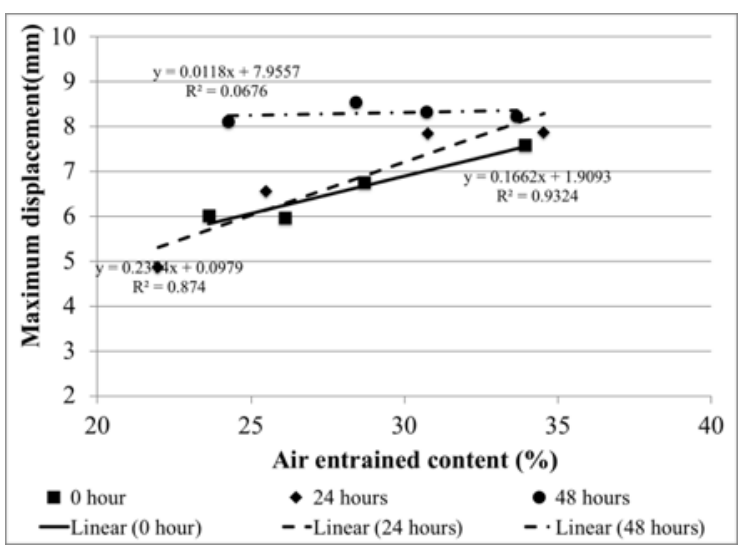

(b)

Figure 12 - Load versus displacement plots obtained by squeeze-flow for all mortars with $\mathbf{1 2 . 0 \%}$ water/ dry materials ratio after: (a) 0 hours; (b) 24 hours; and (c) 48 hours of storage

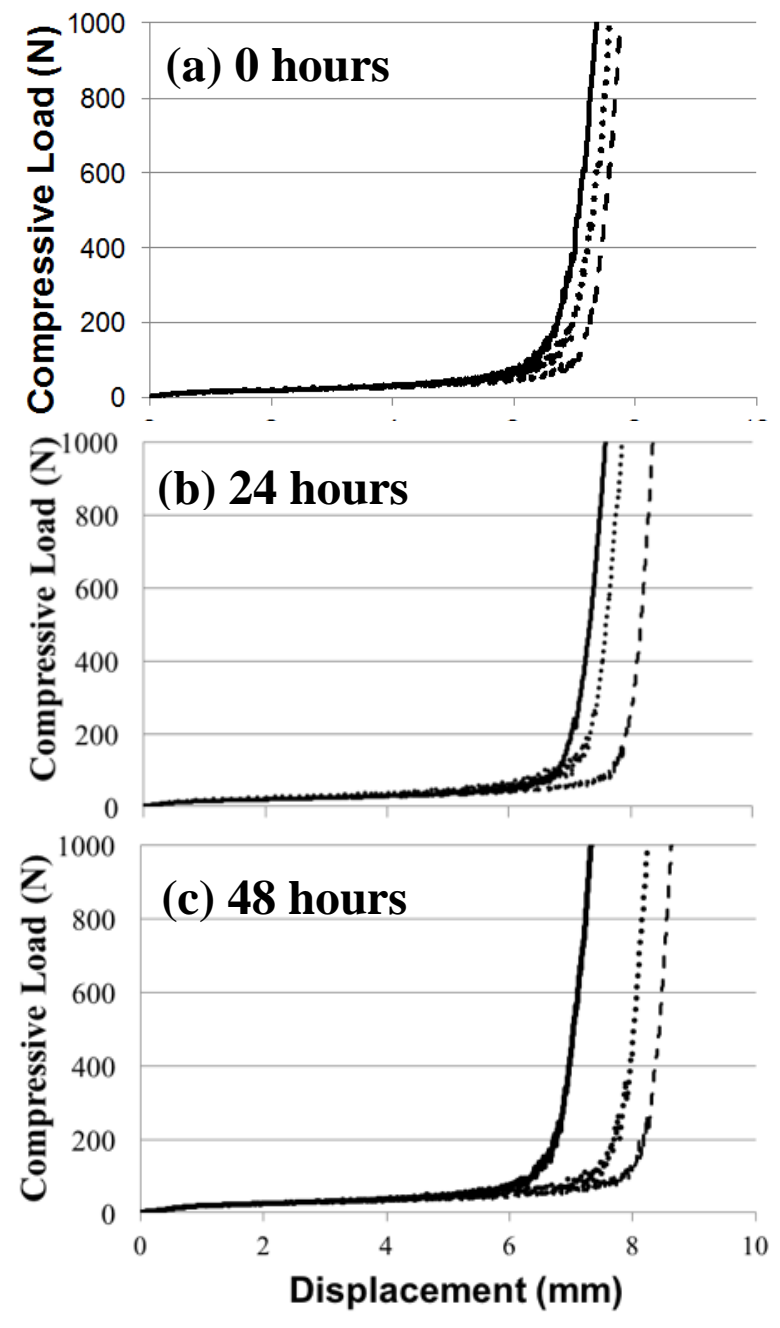

-Cement A - -Cement B $\cdots$ Cement C 


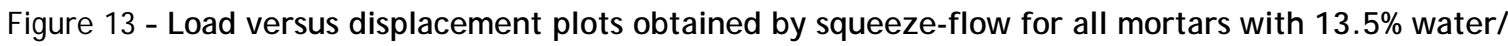
dry materials after: (a) 0 hours, (b) 24 hours and (c) 48 hours of storage

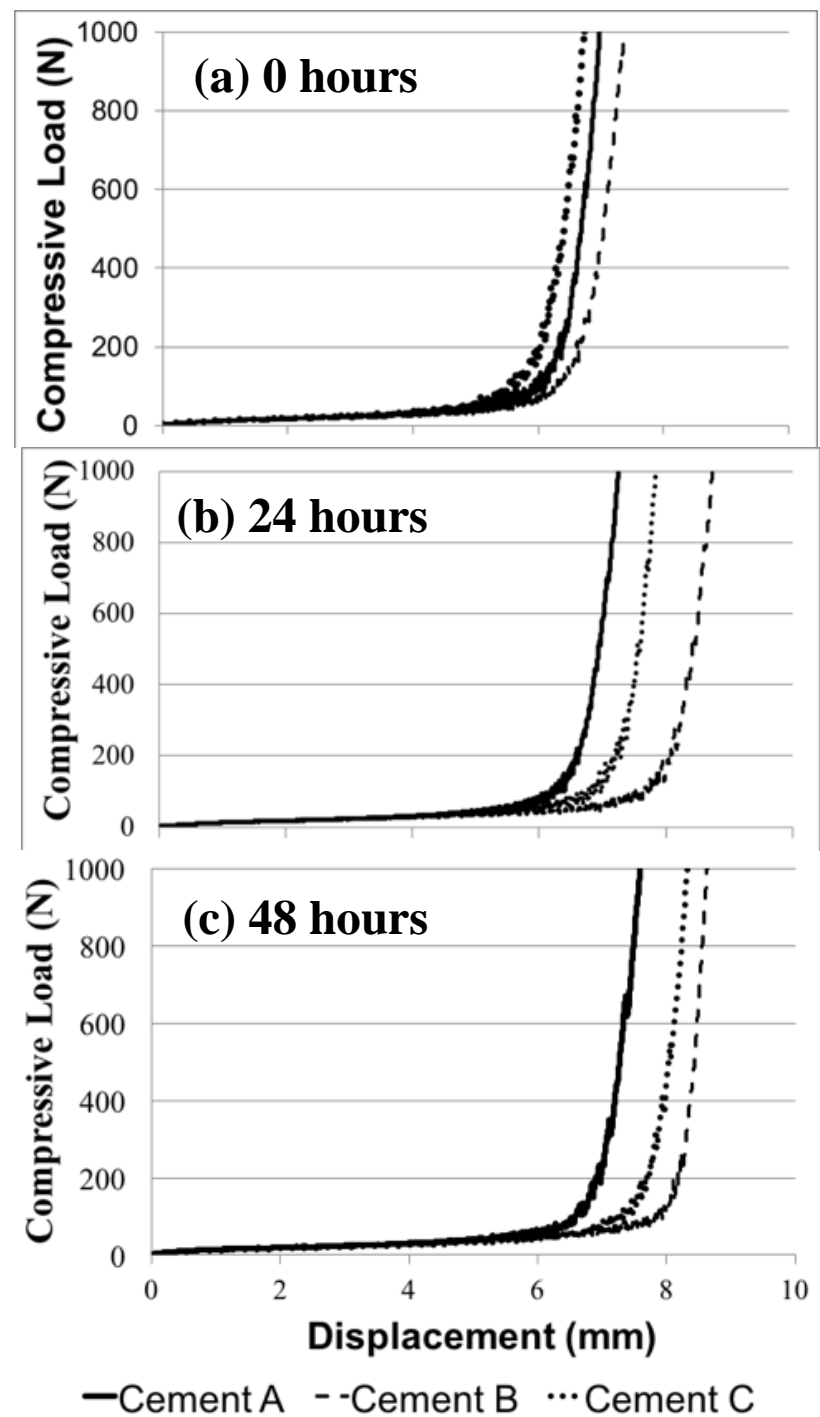

Figures 14 and 15 show the results of the squeeze flow test after 0 hours, 24 hours and 48 hours of storage for the mortars with a $15.0 \%$ water/ dry materials ratio and the mortars with a $16.5 \%$ water/ dry materials ratio, respectively. It is noteworthy that these mortars had the lowest air entrained content (Table 5).

Considering the curves obtained by squeeze flow test for the mortars with the highest water content (15\% and $16.5 \%$ water/dry materials ratio), the strain hardening occurred at lower displacements than for the others mortars that were studied. This behavior is associated with an increase of solid concentration in the central region between the plates related to liquid-solid segregation (CARDOSO; JOHN; PILEGGI, 2009).

As the storage time increased, there was an increase in the maximum displacement of the mortars with the same Portland cement and the differences between the types of Portland cement was observed, which is the same behavior observed for mortars with $12 \%$ and $13,5 \%$ water/cement ratios. The finest Portland cement (Cement B) (Table 1) presented the greatest maximum displacement and for the thickest Portland cement (Cement A) the smaller displacement was observed.

Since the possibility of water loss by evaporation can certainly be discarded, as previously mentioned (there was no mass loss during storage as mentioned in Materials and Methods section), another hypothesis explaining the differences in cement fineness and water content (as measured with the squeeze-flow test) would be a possible loss of the hydration stabilizer admixture's efficiency during storage. This loss of efficiency could have led to the start of the hydration of the Portland cement, contributing to a reduction in the amount of 
available water in the mortar system to produce segregation. In addition, the reduction of the available water in the system allows the particle geometry to have more influence on the displacement of the mortar during the squeeze-flow test, so that cements with added fly ash particles, which are approximately spherical, lead to better roll between particles and a subsequent high displacement. A second effect that can be considered is that, as the amount of available water in the system decreases, the contribution of the air entrained content to mortar displacement in the squeeze-flow test increases, leading to higher displacements.

Figure 14 - Load versus displacement plots obtained by squeeze-flow for all mortars with $15.0 \%$ water/ dry materials after: (a) 0 hours; (b) 24 hours; and (c) 48 hours of storage

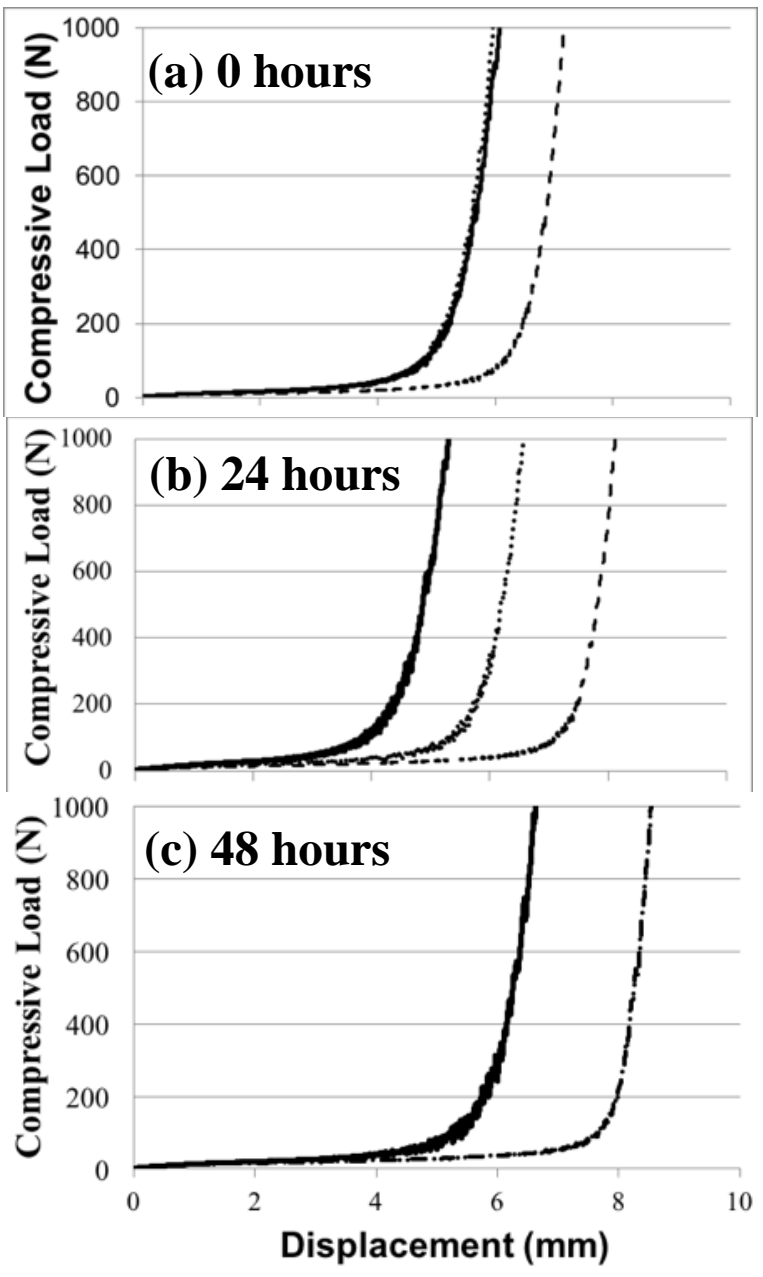

-Cement A - Cement B …Cement C 
Figure 15 - Load versus displacement plots obtained by squeeze-flow for all mortars with $\mathbf{1 6 . 5 \%}$ water/ dry materials after: (a) 0 hours, (b) 24 hours and (c) 48 hours of storage

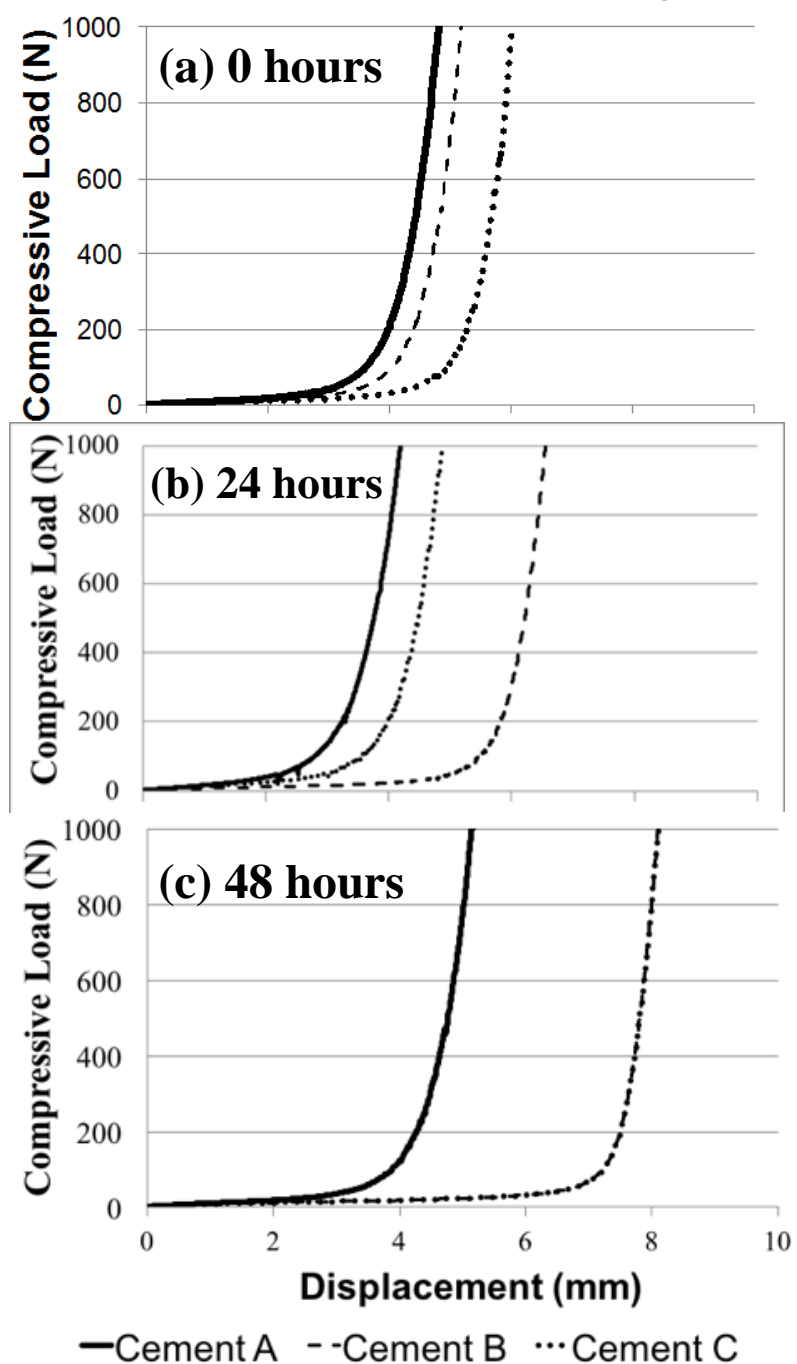

With respect to cement type, the fact that they have different finenesses may be considered. As the fineness increases, the hydration reactions, which consume water, begin earlier. Therefore, considering the same water/dry materials content, the amount of water available to promote displacement decreases earlier for the finest Portland Cement (Cement B), indicating that a high amount of hydration stabilizing admixture would be necessary for this cement to have the same stabilization time. For Portland Cement A - the thickest one - the time necessary for the reactions to begin is greater, leading to more available water for the same storage time and the effect of particle rolling promoted by air entrained content is lesser. Portland Cement $\mathrm{C}$ has an intermediary fineness and, because of this, it presented an intermediary behavior. It is important to mention that for mortars with the same water/dry materials ratio, the incorporated air contents were very close, but the rheological behavior was different according to the type of cement, especially for mortars that were stored for 48 hours.

\section{Conclusion}

These results show the influence of cement type and water/dry materials ratio on the properties of ready mix mortar.

The water/dry materials ratio had a significant influence on air entrained content. However, there was no significant influence from the type of cement on this property. Moreover, storage duration did not influence air entrained content.

For consistency of mortars, the higher the water/dry materials ratio, the greater the consistency index. For the mortars containing $12 \%$ of water/dry materials, there was no difference between the types of cement used, given that these mortars presented 
higher values of air entrained content. Also, there was a loss of consistency index over storage time.

Regarding the rheological behavior by squeezeflow, both the water/dry materials ratio and the air entrained content had influence on the results. In almost all cases, correlations were observed between these parameters and the maximum displacement.

For the mortars that were studied, as the storage time and the Portland cement fineness increased, there was an increase in the maximum displacement observed by the Squeeze Flow test, showing that there are differences between the types of Portland cement that were studied.

The main conclusion of this study is that the rheological properties of ready mix mortar change according to storage time and Portland Cement type has a significant influence on these changes. However, these changes are not noticeable with entrained air content or consistency measurements, which are tests commonly used in production control.

\section{References}

ASSOCIAÇÃO BRASILEIRA DE NORMAS TÉCNICAS. NBR 11578: cimento Portland composto: especificação. Rio de Janeiro, 1997.

\section{ASSOCIAÇÃO BRASILEIRA DE NORMAS} TÉCNICAS. NBR 13276: argamassa para assentamento e revestimento de paredes e tetos: determinação do índice de consistência. Rio de Janeiro, 2005b.

ASSOCIAÇÃO BRASILEIRA DE NORMAS TÉCNICAS. NBR 13278: argamassa para assentamento e revestimento de paredes e tetos: determinação da densidade de massa e do teor de ar incorporado. Rio de Janeiro, 2005a.

\section{ASSOCIAÇÃO BRASILEIRA DE NORMAS} TÉCNICAS. NBR 15839: argamassa para assentamento e revestimento de paredes e tetos: caracterização reológica pelo método squeezeflow. Rio de Janeiro, 2010.

ASSOCIAÇÃO BRASILEIRA DE NORMAS TÉCNICAS. NBR 5736: cimento Portland pozolânico. Rio de Janeiro, 1999.

\section{ASSOCIAÇÃO BRASILEIRA DE NORMAS} TÉCNICAS. NBR NM 248: agregados: determinação da composição granulométrica. Rio de Janeiro, 2003a.
ASSOCIAÇÃO BRASILEIRA DE NORMAS TÉCNICAS. NBR NM 46: agregados: determinação do material fino que passa através da peneira $75 \mu \mathrm{m}$ por lavagem. Rio de Janeiro, 2003b.

\section{ASSOCIAÇÃO BRASILEIRA DE NORMAS} TÉCNICAS. NBR NM 52: agregados: determinação da massa específica e massa específica aparente. Rio de Janeiro, 2009.

BAUER, B. et al. Requisitos das Argamassas Estabilizadas para Revestimento. In: SIMPÓSIO BRASILEIRO DE TECNOLOGIA DE ARGAMASSA, 11., Porto Alegre, 2015. Anais... Porto Alegre, 2015.

BAUER, B.; OLIVEIRA, V. C. Comportamentos e Propriedades das Argamassas Estabilizadas de revestimento. In: SIMPÓSIO BRASILEIRO DE TECNOLOGIA DE ARGAMASSA, 12., São Paulo, 2017. Anais... São Paulo:ANTAC, 2017.

BELLEI, P. et al. Estudo Comparativo do Desempenho no Estado Fresco e Endurecido de Argamassa Estabilizadas de $36 \mathrm{H}$ e $72 \mathrm{H}$. In: SIMPÓSIO BRASILEIRO DE TECNOLOGIA DE ARGAMASSA, 11., Porto Alegre, 2015. Anais... Porto Alegre, 2015.

BENNTER. Recomendações Técnicas Para Utilização da Argamassa Express. 2017. Disponível em: <http://www.bennter.com.br/wpcontent/uploads/2015/07/Aplica\%C3\%A7\%C3\%A 3o-e-Uso-das-Argamassas-Estabilizadas-ProntasBennter.pdf>. Acesso em: 15 nov. 2017.

CALÇADA, L. M. L. et al. Influência das Características do Molde e da Superfície de Contato nas Propriedades da Argamassa Estabilizada. In: SIMPÓSIO BRASILEIRO DE TECNOLOGIA DE ARGAMASSA, 10., Fortaleza, 2013. Anais... Fortaleza, 2013.

CAMPOS, G. M. Estudo do Tempo de Início de Pega de Argamassas Com Aditivo Estabilizador de Hidratação. Curitiba, 2012. 116 f. Monografia (Especialização em Patologia das Construções) Universidade Tecnológica Federal do Paraná, Curitiba, 2012.

CARASEK, H. Argamassas. In: ISAIAS, G. C. (Ed.). Materiais de Construção Civil e Princípios de Ciências e Engenharia de Materiais. São Paulo: Ipsis Gráfica e Editora, 2010. 
CARDOSO, F. A. Método de Formulação de Argamassas de Revestimento Baseado em Distribuição Granulométrica e Comportamento Reológico. São Paulo, 2009. 138 f. Tese (Doutorado em Engenharia Civil) - Escola Politécnica da Universidade de São Paulo, Universidade de São Paulo, São Paulo, 2010.

CARDOSO, F. A.; JOHN, V. M.; PILEGGI, R. G. Rheological Behavior of Mortars Under Different Squeezing Rates. Cement and Concrete Research, v. 39, p. 748-753, 2009.

CASALI, J. M. et al. Avaliação das Propriedades do Estado Fresco e Endurecido da Argamassa Estabilizada Para Revestimento. In: SIMPÓSIO BRASILEIRO DE TECNOLOGIA DE ARGAMASSA, 9., Belo Horizonte, 2011. Anais.... Belo Horizonte, 2011.

FERNANDES, A. Avaliação da Variabilidade das Propriedades da Argamassa Estabilizada Fornecida Para a grande Florianópolis. Florianópolis, 2011. Trabalho de Conclusão de Curso (Curso Superior de Tecnologia em Construção de Edifícios) - Instituto Federal de Tecnologia, Ciência e Educação de Santa Catarina, Florianópolis, 2011.

FIORAVANTE, E. V. Influência dos Aditivos nas Propriedades de Argamassas Estabilizadas. Ponta Grossa, 2014. Trabalho de Conclusão de Curso (Engenharia de Civil) - Universidade Estadual de Ponta Grossa, Ponta Grossa, 2014.

JANTSCH, A. C. A. Análise do Desempenho de Argamassas Estabilizadas Submetidas a Tratamento Superficial Com Aditivos Cristalizantes. Santa Maria, 2015. Dissertação (Mestre em Engenharia Civil) - Escola de Engenharia, Universidade Federal de Santa Maria, Santa Maria, 2015.

KEBHARD, J. M.; KAZMIERCZAK, C. S. Avaliação do Comportamento de Uma Argamassa Estabilizada ao Longo de Seu Tempo de Estabilização. In: SIMPÓSIO BRASILEIRO DE TECNOLOGIA DE ARGAMASSA, 12., São Paulo, 2017. Anais... São Paulo, 2017.

MACIOSKI, G. Avaliação do Comportamento de Argamassas Estabilizadas Para Revestimento. Curitiba, 2014. Trabalho de Conclusão de Curso (Engenharia de Civil) Universidade Federal do Paraná, Curitiba, 2014.

MACIOSKI, G. et al. Avaliação das Propriedades do Estado Fresco e Endurecido da Argamassa Estabilizada. In: SIMPÓSIO BRASILEIRO DE TECNOLOGIA DE ARGAMASSA, 10., Fortaleza, 2013. Anais... Fortaleza, 2013.
MANN NETO, A.; ANDRADE, D.C.; SOTO, N. T. A. Avaliação das Propriedades do Estado Fresco e Endurecido da Argamassa Estabilizada Para Revestimento. Curitiba, 2010. Trabalho de Conclusão de Curso (Engenharia de Produção Civil) - Universidade Tecnológica Federal do Paraná, Curitiba, 2010.

MARTINS NETO; N. A. A. A.; DJANIKIAN, J. G. Aspectos de Desempenho da Argamassa Dosada em Central. Boletim Técnico da Escola Politécnica da USP. São Paulo serie BT/PCC/235, 1999.

MATTANA JÚNIOR, A.; COSTA, M. R. M. M. Estudo da Influência do Tipo de Cimento no Comportamento Reológico de Argamassas de Revestimento. In: SIMPÓSIO BRASILEIRO DE TECNOLOGIA DAS ARGAMASSAS, 8., Curitiba, 2009. Anais... Curitiba, 2009.

NELSON, R. L. et al. Ready Mix Mortar in the United States. In: INTERNATIONAL BRICK AND BLOCK MASONRY CONFERENCE, 8., Dublin, 1988. Proceedings... Dublin, 1988.

NICHOLSON, R. Extended Life Ready-Mixed Mortars for Masonry Construction. In: INTERNATIONAL NORTH AMERICAN MASONRY CONFERENCE, 4., California, 1987. Proceedings... California, 1987.

NUNES, J. C. D. P. Argamassa Estabilizada Pronta Para Uso Sistema Mormix. Blumenau, 2010. Trabalho de Conclusão de Curso (Engenharia Civil), Universidade Regional de Blumenau, Blumenau, 2010.

PAGNUSSAT, D. T.; VIDOR, D.; MASUERO, A. B. Avaliação de Propriedades de Argamassas Estabilizadas ao Longo do Seu Tempo de Utilização. In: CONGRESSO PORTUGUÊS DE ARGAMASSAS, 4., Coimbra, 2012. Anais.... Coimbra, 2012.

PANARESE, W. C, KOSMATKA, S. H., RANDALL JUNIOR, F. A. Concrete Masonry Handbook for architects, Engineers, Builders. 5. ed. Estados Unidos da América: Portland Cement Association, 1991.

PEREIRA, L. Estudo das Propriedades da Argamassa Estabilizada Para Revestimento: influência das características do molde, do tempo e das condições de armazenamento. Florianópolis, 2012. Trabalho de Conclusão de Curso (Curso Superior de Tecnologia em Construção de Edifícios), Instituto Federal de Tecnologia, Ciência e Educação de Santa Catarina, Florianópolis, 2012. 
PIVETTA, D. M. et al. Desempenho de Argamassas Estabilizadas: influência do aditivo estabilizador de hidratação no estado fresco. In: CONGRESSO BRASILEIRO DO CONCRETO, 58., Belo Horizonte, 2016. Anais... Belo Horizonte, 2016.

ROMANO, R. C. O. Incorporação de Ar em Materiais Cimentícios Aplicadas em Construção Civil. São Paulo. 2013. Tese (Doutorado em Engenharia Civil) - Escola Politécnica, Universidade de São Paulo, Universidade de São Paulo, São Paulo, 2013.

RUPPENTHAL, S. M.; PELISSER, F. Estudo de Argamassas de Revestimento Com Inibidores de Hidratação. 2012. Disponível em: <http://200.18.15.27/bitstream/1/1158/1/Suelem\% 20Michels\%20Ruppenthal.pdf $>$. Acesso em: 16 nov. 2017.

SUPERMIX. Supermassa: a argamassa inteligente da Supermix. 2017. Disponível em: $<$ http://www.supermix.com.br/wpcontent/themes/supermix/assets/files/cartilhaargamassa.pdf $>$. Acesso em: 16 nov. 2017.
TREVISOL, L. A.; PORTELLA, K. F.; BRAGANÇA, M. O. G. P. Estudo Comparativo Entre as Argamassas: estabilizada dosada em central, industrializada e produzida em obra por meio de ensaios físicos nos estados fresco e endurecido. In: SIMPÓSIO BRASILEIRO DE TECNOLOGIA DE ARGAMASSA, 10., Porto Alegre, 2015. Anais... Porto Alegre, 2015.

TURRA, D. G. Contribuições Para o Estudo de Algumas Propriedades no Estado Fresco e Endurecido da Argamassa Estabilizada por 72 Horas. Porto Alegre, 2016. Trabalho de Conclusão de Curso (Engenharia Civil) - Universidade Federal do Rio Grande do Sul, Porto Alegre, 2016.

\section{Acknowledgements}

This research was conducted with financial support from the Federal Institute of Education, Science and Technology of Santa Catarina (IFSC) through EDITAL N ${ }^{\circ}$ 03/2016/PROPPI. The authors wish to thank the companies that provided the Portland cement, admixtures and sand. The authors are also grateful for the support of the Technological Research Center (NPT) of the Federal Technological University of Paraná (UTFPR).

J uliana Machado Casali

Departamento Acadêmico de Construção Civil | Instituto Federal de Santa Catarina | Av. Mauro Ramos, 950, Centro | Florianópolis - SC Brasil | CEP 88020-300 | Tel.: (48) 3211-6000 | E-mail: juliana.casali@ifsc.edu.br

Fernanda Domigues Melo

Departamento Acadêmico de Construção Civil | Instituto Federal de Santa Catarina | E-mail: fefinhadm@gmail.com

Vitoria Carminatti Serpa

Departamento Acadêmico de Construção Civil | Instituto Federal de Santa Catarina | E-mail: vitoriacserpa@gmail.com

Alexandre Lima de Oliveira

Departamento Acadêmico de Construção Civil | Instituto Federal de Santa Catarina | E-mail: alexandre@ifsc.edu.br

Andrea Murillo Betioli

Departamento Acadêmico de Construção Civil | Instituto Federal de Santa Catarina | E-mail: andrea.betioli@ifsc.edu.br

Luciana Maltez Lengler Calçada

Departamento Acadêmico de Construção Civil | Instituto Federal de Santa Catarina | E-mail: Iucianamaltez@ifsc.edu.br

Revista Ambiente Construído

Associação Nacional de Tecnologia do Ambiente Construído

Av. Osvaldo Aranha, 99 - 3o andar, Centro

Porto Alegre - RS - Brasil

CEP $90035-190$

Telefone: +55 (51) 3308-4084

Fax: +55 (51) 3308-4054

www. seer. ufrgs. br/ ambienteconstruido

E-mail: ambienteconstruido@ufrgs.br

(c) (i) 